\title{
ENCONTROS E DESENCONTROS EM NARRATIVAS DE HAITIANOS NA AMAZÔNIA ACREANA $^{1}$
}

Armstrong da Silva Santos ${ }^{2}$

\section{RESUMO:}

Entre 2010-2014, milhares de sujeitos provenientes do Haiti ingressaram no território brasileiro através das cidades acreanas fronteiriças a Bolívia e Peru. Neste transcurso, no diálogo com a recepção e com os discursos formulados sobre suas presenças no Brasil, esses sujeitos elaboraram formas diferenciadas de identificação. Neste estudo, buscamos compreender como esses diálogos repercutiram/repercutem na vida dos que vivenciaram tais experiências socioculturais em meio às tensões do debate jurídico/linguístico que gira em torno da "legalidade" de suas presenças/permanências no Brasil. Realizamos coleta e análise de entrevistas, reportagens de jornais e diversificados tipos de outros documentos alinhavados em uma proposta de reflexão sobre as narrativas produzidas sobre e por esses sujeitos. Essa proposta foi discutidas com base nas proposições de Stuart Hall, Paul Ricoeur, Hannah Arendt e Edouard Glissant, entre outros. Autores fundamentais para compreendermos algumas dimensões das violências e dos papéis destinados a populações de afrodescendentes no continente americano na atualidade.

PALAVRAS-CHAVE:

Diáspora haitiana. Narrativas identitárias. Experiências de tradução. Amazônia acreana

\section{INTRODUÇÃO}

A globalização econômica recente, as crescentes dificuldades vivenciadas por diversos grupos humanos, as possibilidades abertas pelas tecnologias de transporte, informação e comunicação e a mobilidade de indivíduos em busca de melhores condições, nos têm possibilitado o acesso a narrativas identitárias provenientes dos mais distintos recantos. Esses contatos e trocas culturais, em si, não são novidades, a diferença reside no fato de que eles se dão com uma velocidade nunca experimentada, ocasionando tensões e conflitos mais acentuados e complexos.

Essas tensões são potencializadas nas áreas de fronteira política dos Estados Nacionais, quanto mais em decorrência de algum evento que agrave a situação vivenciada por populações de países ou regiões distanciadas dos benefícios da "economia global", cujos sujeitos nutram em relação a determinados territórios, laços de afetividade que tentam satisfazer. $\mathrm{Na}$ ânsia por inserção nesse universo de benefícios "prometidos", emigram, ficando mais visíveis (como imigrantes) para quem vive nos países de destino.

No caso dos haitianos, a destruição e as mortes causadas pelos sismos de janeiro de 2010, tem funcionado como fatores de repulsão, acelerando fluxos migratórios. Por outro lado, o crescimento econômico brasileiro, a presença e a atuação do Brasil junto às forças da ONU naquele país e a apresentação do "Brasileiro" no cenário mundial, como "um povo acolhedor e alegre" têm agido como fomentadores do desejo e da procura pelo ingresso dessas pessoas no território nacional do Brasil. Em meio a essa busca, sucedem diversas tentativas de transformação destes indivíduos, desde o Haiti, em mão de obra barata por uma série integrada de processos práticos e discursivos de desumanização que visa exatamente esse resultado.

Nos últimos meses de 2010, pequenos grupos de haitianos começaram, com maior intensidade, a penetrar no Brasil através da Bolívia e do Peru, respectivamente pelos municípios acreanos de Brasileia e Assis Brasil. Com o aumento do número desses indivíduos que alcançavam aqueles municípios, houve, nos primeiros meses de 2011, por parte do Governo Federal Brasileiro, uma restrição do acesso à documentação necessária à legalização de suas estadias, permanências e/ou circulação em terras brasileiras. É justamente nesse ponto que a presença haitiana no Acre adquire maior visibilidade 1 Texto originalmente apresentado como parte do primeiro capítulo da dissertação de mestrado intitulada Haitianos na Amazônia SulOcidental: identidades e narrativas em trânsito, junto ao Programa de Mestrado em Letras: Linguagem identidade da Ufac, em setembro de 2014.

2 Mestre em Letras e Professor da Universidade Federal do Acre. 
em reportagens de TV, jornais, blogs e sites, que veiculam posicionamentos oficiais e extraoficiais sobre a questão.

Quando o acesso à documentação foi restringido, cresceu o número de haitianos a ocupar espaços públicos e privados, principalmente do município de Brasileia. O "aparecimento" dos imigrantes haitianos como "problema" a ser "sanado" se evidencia exatamente em função das tentativas de fazer com que aquelas pessoas se mantivessem fora do campo de visão. Foi o "represamento" do processo imigratório o gerador da expressão numérica preponderante para a visibilidade, uma vez que não se falava em haitianos no Acre antes desse período, apesar deles existirem.

A confirmação trazida pela incidência do olhar e pela posterior enunciação sobre essa presença inquestionável do "outro", nos permite discutir a relatividade dessa situação. Chegar e partir é uma questão de perspectiva, sendo que a meta anunciada é a da integração mediada pelo emprego e pela aquisição das condições necessárias para auxiliar os familiares que permaneceram no Haiti. Caso o objetivo não seja alcançado, o ponto de chegada pode ser deslocado para algum lugar "além da próxima fronteira": do bairro, da cidade, do estado, do país, etc.

A presença haitiana no Acre, crescente desde o final do ano de 2010, torna evidente a complexidade desses encontros que fazem sobressair as diferenças também nesta parte da Amazônia Sul-Ocidental. Por outro lado, ela possibilita, a partir das práticas e dos discursos, refletir sobre a dinâmica dessas vivências e as interpretações elaboradas no contato com os brasileiros, na relação que estabelecem com o tempo e com as atividades que desenvolvem e/ou se propõem a desenvolver no Brasil.

O contato com pessoas provenientes de países sobre os quais só tínhamos ouvido falar vagamente, com hábitos alimentares, idiomas diferentes, além de práticas religiosas sobre as quais conhecemos apenas, e quando muito, os nomes, se tornam estranhamente presentes, atestando uma verdade há muito esquecida: a de que "não estamos sós!"

A presença aparentemente "alienígena" de pessoas praticantes de "ações significativas" (HALL, 1997, p.16) tão diversas daquelas às quais estamos habituados, traz à baila a problemática de lidar com a alteridade, não apenas com a que viria de fora, mas também com aquela que estaria no interior de nossas próprias práticas culturais, desconstruindo a produção significativa de nossa mesmidade, instituímos novos sentidos para nossa identidade a partir da ação social.

Genericamente denominados de haitianos, sujeitos sociais com as mais variadas trajetórias, têm adentrado o território nacional brasileiro através dos municípios acreanos de Assis Brasil, Brasileia e Epitaciolândia. São centenas de homens, mulheres e crianças que articulam seus modos de agir na interpretação do vivido e reelaboram suas experiências através da memória transformada em narrativa (BENJAMIN, 1987, pp.197-221). Dentre esses sujeitos podemos encontrar pessoas que têm atuado profissionalmente como professores, técnicos em refrigeração, mestres de obras, carpinteiros, serralheiros, estudantes, pastores religiosos, agricultores, etc. Sujeitos que falam das atividades laborais que desenvolviam no Haiti ou em outros países, indicando possibilidades de continuar trabalhando (no que puderem) também aqui no Brasil. De modo semelhante à sua identificação como o que seria um grupo homogeneamente constituído, eles são denominados e se autodenominam haitianos e são, em grande medida, visualizados como mão de obra, principalmente utilizável na construção civil brasileira.

Alguns deles, notadamente os homens, falam de suas experiências na República Dominicana, onde aprenderam o Espanhol; tratam dos vários anos que viveram por lá, das dificuldades em se conseguir o visto de permanência naquele país e da necessidade de continuar mudando em busca de melhoria de vida. Outros abordam os horrores ocasionados pelo tremor de 12 de Janeiro de 2010 e agradecem por não terem perdido nenhum parente na catástrofe. Alguns já não tiveram tanta sorte, perderam 
casa, carro, loja, parentes e amigos durante o sismo e visam, através da imigração, "reconstruir o que se perdeu”.

Suas falas são repletas de contradições, de "conformismos" e "resistências" (CHAUÍ, 1986) que se relacionam às lides cotidianas repercutindo nas maneiras de perceber, identificar, agir e reagir. Neste sentido, as narrativas que são constituídas a respeito dos espaços de convivência ou "zonas de contato" (PRATT, 1999) entre haitianos e brasileiros incidem significativamente sobre as identidades culturais dos praticantes dessas "zonas".

Um desses sujeitos, o haitiano Tervenkus Petit, 37 anos, casado com a haitiana Ãnia Silvalien, com quem teve dois filhos (o mais novo nascido no Brasil), um de oito anos e o outro seis meses à época, nos falou, em entrevista, de suas expectativas; da recepção oferecida por instituições do Brasil e da relação estabelecida com o território e as pessoas desde sua "chegada" ao Acre:

(...) fomos chegar em Brasileia três horas de madrugada. Aí eu cheguei lá na praça de frente, aí ele, ele, ele mostrou pra nós aonde tava os outros haitiano, num hotel que tem na frente da praça. Aí nós entramo lá. Aí, aí depois é teve reunião todo dia com um grupo, não sei aonde vinha, daonde eles vieram, se era de Brasília, não sei! Mas todo dia era reunião sobre reunião (pausa) é entrevista, sobre entrevista, direto! Aí depois passei três meses lá em Brasileia pra arrumar os documentos, CPF, Carteira de Trabalho, passei três meses lá. Aí de três messes saí de lá pra chegar até aqui em Rio Branco, até hoje tô aqui, por enquanto, trabalhando (pausa). Demorei três meses porque era muito, é e era mais devagar a documentação, agora é mais ligeiro né? É mais rápido agora, mas naquela época era mais, um pouco mais complicado e era mais devagar. E aqui eu fiquei, trabalhando, até hoje, num (pausa) teve, ééé, intenção de sair daqui. O Português? Trabalho? A minha Profissão? Não eu saí de lá com ela. Eu trabalhava de, de pedreiro desde, da República Dominicana. Eu morava lá, estudei lá também, aí eu saí de lá com essa (pausa/procurando a palavra) profissão de trabalho de pedreiro. Eu sou técnico também de refrigeração, só que faz tempo que eu não trabalho mais. Eu tô mais apegado na construção porque é mais fácil de arrumar e dá mais dinheiro. Mais fácil, e também dá mais dinheiro (...) Bom, na verdade é quando eu cheguei aqui em Rio Branco eu, eu fui, eu fui atendido peloooo. Como se chama aquele coisa é (pausa) deixa ver, esqueci o nome éé, é as pessoas que davam, que, que sempre dá apoio pras pessoas que vêm de fora? Não conhece ninguém? Você sabe onde que fica? Não tem a Polícia é Federal, que fica por éé, Assistência Social! Eu fui atendido pela Assistência Social, mas atendido não por eles mesmo não, é por (pausa) teve as pessoas que, que que foi, que arrumou o serviço pra nós, que é, é Maria da Luz. El, Ela trabalhava na Assistência Social, agora ela, ela passou pra (pausa), ela passou pra Direitos Humanos. Conhece né!? Ela foi uma pessoa ótima! Até hoje eu, eu agradeço a ela porque foi ela que arrumou serviço pra mim no Araújo. Até hoje tô no Araújo, com dois anos. Até hoje ela ficou sendo amiga da, da gente. Ela foi uma pessoa ótima, não só pra mim, pra todos os haitiano que chegou aqui no Brasil. Ela deu muito apoio, mas o primeiro que eu ficava hospedado foi lá no, no JOCUM. Ouviu falar da Igreja da Batista? Ele têm um (pausa) é, lá só é um local que ela coloca pra, pra atender pessoas que não têm onde ficar, por um tempo, eles chamam "JOCUM". Fica perto da OCA, do lado! Eu acho que já foi vendido, porque lá eu tô vendo uma construção que fizeram lá. Ma eles não tão mais lá, mas tem um ou dois, entendeu? Eu fui atendido por esse grupo (PETIT, 02/06/2013).

No Brasil há quase dois anos no momento da entrevista, Tervenkus Petit nos oferece uma referência a partir da qual podemos perceber várias formas de identificação elaboradas no percurso, refeito através da memória, do Haiti ao Brasil elaborando uma narrativa pautada pelas experiências de trabalho vivenciadas principalmente na República Dominicana. A profissão exercida por ele desde aquele país se torna eixo de identificação, no entanto, não é como pedreiro que Tervenkus Petit se identifica. Ele afirma que trabalha "de pedreiro" e logo em seguida diz que "é” técnico em refrigeração. A fórmula escolhida por Tervenkus Petit, para falar do trabalho que tem exercido, pode sugerir certa preferência em relação à lida com refrigeradores se comparada com a atividade de pedreiro. Preferência suprimida pelas necessidades objetivas de existência que o fazem ficar "mais apegado na construção".

Outra identificação que figura no relato é em relação ao espaço, apresentado como pertencente a outros (territórios). Ao falar de sua "chegada", Tervenkus Petit se assume enquanto estrangeiro e faz isso quando lhe são indicados e também reconhecidos os "outros haitianos" que, como ele, haviam "chegado" à Brasileia. Como na poesia de Patativa do Assaré, Tervenkus Petit não reconhece 
as paisagens familiares que lhe ofereceriam a segurança do pertencimento, "tudo é diferente, do carro ao torrão" (ASSARÉ, 1978), e, em meio a esse estranhamento, ele reconhece a si e aos demais haitianos como "estrangeiros", que podem, nesses primeiros contatos com o "ambiente estranho", servir de apoio mútuo.

Aqueles que "chegam”, estão reconfigurando suas "narrativas identitárias” (RICOEUR, 1994) a partir das situações em que estão; das relações estabelecidas com o local (espaço e população) e através de aparatos jurídico/linguísticos, que os identificam como imigrantes, haitianos, trabalhadores, negros, pobres, necessitados, etc. "Chegar", nesse sentido, representaria esse estado de coisas vivenciadas pelos indivíduos enquanto calculam o quanto da meta inicial de "construir a vida", foi realizada. Esse cálculo, inscrito na realidade da vida vernácula, incide sobre as formas de identificação desses sujeitos que falam do sendo, apresentando-o como o ser. As necessidades comunicativas põem freio no movimento e o apresentam como estanque e limitado para discorrer sobre ele.

Os "chegantes" são transformados, por esses mesmos aparatos e na interação com eles, em "legais" ou "ilegais". Seguindo uma lógica binária e limitada, as diferenças são rapidamente apresentadas como ameaças que legitimariam ações visando a restrição das liberdades de circulação, confinando esses sujeitos a espaços em que a morosidade da espera pelos documentos cria "depósitos" de uma valiosa, mas barata, mão de obra pronta para a arregimentação de empresários que atravessam o Brasil para encontrá-la e utilizá-la (legal ou ilegalmente) em suas empresas e/ou negócios.

Essa é a intenção velada que torna "necessária" a morosidade na recepção aos imigrantes provenientes do Haiti. No entanto, da chegada à arregimentação, outras relações são estabelecidas entre os que chegam e os que aqui estão, através das práticas efetivadas sobre os territórios em que esses encontros se dão. As proibições e interditos aos quais são submetidos os imigrantes, não passam despercebidos e, em vez de esconder, tornam evidentes as contradições aí inscritas. A partir delas, outras grafias vão sendo acrescentadas, pois "a fantasia de um significado final continua assombrada pela 'falta' ou 'excesso', mas nunca é apreensível na plenitude de sua presença a si mesma” (HALL, 2003, p.33).

É nesse embate entre as expressões que visam o fechamento dos significados e os usos linguísticos muito mais "deslizantes", que encontramos o palco sobre o qual se travam as traduções culturais e as manifestações das sociabilidades e identidades, inscritas nesses processos de significação e (re)significação. Entre uma formalização linguística que encerra e limita e uma realidade prática que abre e permite, são reorientados os fazeres (re)significando posicionamentos sociais. A formalização "assombrada" pelo "fantasma" de suas próprias impossibilidades, apresenta-se ressentida pela presença daquilo que, na realidade, é a consciência dela mesma, incompleta e impotente frente a essa incompletude.

A dinâmica da experiência que conforma tempo, mobilidade e atividades é evidenciada na narrativa construída por Tervenkus Petit, principalmente quando trata da ajuda prestada por instituições e indivíduos que nelas trabalham. Chamamos atenção neste ponto para a relação estabelecida pelo narrador que associa ajuda e emprego. Ao mesmo tempo em que agradece aos préstimos recebidos, Tervenkus Petit une o tempo de serviço à duração da amizade dedicada a quem lhe possibilitou o trabalho. Aliás, a própria permanência dele no Acre está intimamente ligada à atividade remunerada por ele exercida.

O "até hoje tô aqui, por enquanto, trabalhando" enunciado por ele, significa não apenas que seu serviço é provisório (enquanto durar a construção), mas também que a permanência dele em Rio Branco está ligada às perspectivas de trabalho e renda aqui disponíveis. Isto pôde ser confirmado meses mais tarde, quando, terminada a construção, os trabalhadores foram dispensados e Tervenkus Petit se dirigiu ao estado do Mato Grosso em companhia da família e de um amigo, também haitiano, à procura de serviço. 
Retornando ao tema das formas de identificação, a associação religiosa tem atuado como facilitador na interação entre os imigrantes e destes com a localidade de ingresso. A presença de indivíduos que se declaram cristãos, principalmente evangélicos, entre os haitianos que estão no Acre é significativa. A existência de templos e locais de acolhida organizados por membros dessas comunidades religiosas pode nos fornecer pistas importantes para pensarmos sobre esses atos confessionais, acompanhando aquilo que Stuart Hall (2003) analisou como preferências identitárias.

Da narrativa de Tervenkus Petit, que é Adventista do Sétimo Dia, destacamos o atendimento recebido por ele através das ações da JOCUM (Jovens Com Uma Missão), entidade organizada por membros da Igreja Batista no Acre. De acordo com ele, a atenção é oferecida de forma irrestrita a todos "que não têm onde ficar, por um tempo", no entanto, a aproximação promovida pela declaração de crença ou pela participação nos cultos realizados em instituições religiosas pode tornar mais fácil a acolhida e a aquisição de emprego, como nos contou o narrador.

Em uma perspectiva muito semelhante às práticas religiosas correntes no Brasil, entre os imigrantes haitianos, assumir-se como adepto de determinada religião, pode representar auxílio, possibilidades de emprego e renda, isso em razão da rede de contatos e convivências que se estabelecem entre os praticantes desses credos. Para além do conforto espiritual e do conhecimento acerca dos ensinamentos valorizados nesses cultos, está em jogo a questão da sobrevivência e da melhoria das condições gerais de vida. Na diáspora haitiana (como em várias outras), torna-se comum a ideia de um "destino" em que se coadunem o pertencimento a uma comunidade (religiosa e/ou nacional) e as benesses ofertadas por um Deus a seus fiéis seguidores.

Enunciações semelhantes em termos de trabalho e religiosidade foram encontradas nos posicionamentos transformados em narrativa por Guinot Gerlin, haitiano, 36 anos, casado e pai de uma filha que ainda vive no Haiti junto da mãe. Ele também viveu na República Dominicana, onde estudou e trabalhou por vários anos.

Tem Assembleia de Deus, Batista, tem quase todo tipo, quase tudo! Só Quadrangular, eu já vi aqui, mas não sei se tem outro nome lá. Não sei! Mais só isso, só isso eu percebi que é um pouco diferente [...] O Vodu? É ele tá também! Tem o Vodu também, só que é, esse Vodu é, tá aí na cultura africano. Ali, a gente, como nós somos assim, descendentes da África, a gente ter, ficar, ficar, como a cultura [...] Só que é assim, mesmo que a pessoa sempre são Vodu, mesmo é, pessoa é, como chamar, é, a crença do Vodu, a coisa do Vodu, chama de. Aqui chama de, tem um nome é (pausa tentando recordar o nome do praticante do vodu) é Macumbá! É do Macumbá. É macumbeiro, é eles lá mesmo que as pessoas é uma macumba, eles são da Igreja porque já é católico, são católico. Foi na igreja Católica. Isso é quando você encontra uma pessoa que nunca foi na igreja, encontra alguma pessoa e diz: "você pratica alguma religião"? "Sim, sou católico"! (risos) É assim, mas é que o católico todo mundo já pratica, mas é, é, outras religião, como a Batista, a Adventista, eles, se já adventista, eles não vai gostar do vodu. Não vai! Não vai, não pratica mais, que isso tem, tem é, direito com o Satanás! (risos) (GERLIN, 11/08/2013).

Ao elencar semelhanças e diferenças entre algumas das religiões e igrejas existentes no Haiti e no Brasil, Guinot Gerlin evidencia possibilidades de estabelecer com elas e/ou através delas, relações de sincretismo e exclusividade. $\mathrm{Na}$ voz do narrador, tanto uma quanto a outra possibilidade, quando enunciadas na autorreferência, ocorrem na mediação entre interlocutores. Ser praticante do Vodu e declarar-se católico é ação comum que, de acordo com Guinot Gerlin, marca duas tradições religiosas: uma de matriz europeia e a outra africana. A primeira delas, decorrente da presença católica no Haiti desde o início do (e em relação com o) processo colonizador, impõe a prática do batismo para as crianças tornando-as "católicas" mesmo que, no futuro, não frequentem as igrejas dessa religião. A segunda, o Vodu, também decorre do processo colonizador e se inscreve no elaborado conjunto das trocas culturais engendradas por indígenas, africanos escravizados e europeus, mas que na enunciação de Guinot Guerlin, representa a descendência africana inscrita sobre o Haiti. 
Mas se as duas tradições remontam ao processo colonizador, por que se declaram católicos e não vuduístas aqueles que, de acordo com Ginot Guerlin, são questionados? Exatamente em razão da organização e hierarquização do sistema colonial e escravagista que apresentava a religião europeia como superior e correta. Esse traço, apesar das resistências, dos diálogos e sincretismos que se estabeleceram ao longo do tempo, permaneceu, podendo influenciar as formas de identificação religiosa dos haitianos praticantes do Vodu. Assim, ao abandonar essas práticas e aderirem às religiões "Batista" e "Adventista", essas pessoas buscam se reposicionar socialmente em um universo que "não vai gostar do Vodu", muito menos de seus praticantes.

O fenômeno da "dupla consciência" (GILROY, 2001) se apresenta na narrativa de Guinot Guerlin. Concomitante ao autorreconhecimento de uma ancestralidade africana representada pelo "nós somos", ele reproduz o discurso colonizador que, além de hierarquizar, transforma outras manifestações religiosas em práticas "demoníacas". Para ele, aquilo que ficou "como a cultura" (de matriz africana) e marca daquilo que "nós somos" (negros do Haiti), também acaba sendo demonizado, pois teria "direito com o Satanás". É na tentativa de escapar a essa associação e estabelecer outras que, em muitos casos, a autorreferência como católicos, batistas, adventistas, etc., ocorre.

Voltando ao tema do papel desempenhado pelas narrativas de trabalho nos processos de identificação e acolhida, Gunot Guerlin diz que quando

chegou à Brasileia, a gente entregar o documento, que tinha ali. E as pessoas que tava lá, ele (pausa) faz uma inscrição e manda pro é Federal, ali o Federal entrega um número para nós, o número já para entregar para nós o CPF. Entregar o CPF. Já saí de lá pra chegar até aqui, Rio Branco. Chegou aqui Rio Branco, é (pausa) não é muito, muito bom, mas é mais ou menos, porque eu não tinha ninguém aqui em Rio Branco. Chegou aqui já, eu encontrou um amigo, o amigo ajudar a buscar um emprego, mas no, no emprego, eu não gosto a forma de tratar, mas eu não fico, dentro da empresa. Eu sai de dentro da empresa, fui atrás de outra, aí eu passou um tempo também na outra, não era bom! Porque eles fala mentira para mim, porque diz que trabalhar quarenta e cinco dia pra receber, mas disse que a, a lei do país é assim. Eu sabia que não! Eu saí de dentro da empresa, e fui atrás de outro. $\mathrm{Eu}$ vi, eu encontrou uma empresa que trabalha construir a praça Gameleira, aí eu ficou dentro dessa empresa trabalhando junto com eles. Passou seis meses trabalhando e depois já acabou a obra, a gente foi embora. Mas com a relacionamento com os brasileiro é muito bom, muito bom, faz muitas amizades com as pessoas, com as pessoas da igreja é mais, muito interessante! Sempre eles convida nós pra casa dele, nos convida pra saí junto. Fui passear, fui na mata, fui (risos) muito bom, muito interessante, ali! Eu ficou aqui, é muito bom! Eu gosto! [...] Eles me ajudar, da maneira que pode, que pode! Mas é, é como foi alugar uma casa pra morar; pro eu alugar minha casa, o encanamento que eu pagou a casa e ajuda da maneira que eles pode! Então, lá no Haiti, eu não, não sabia muito sobre o Brasil! Só, eu sabia só o futebol! Porque já todo mundo de lá gosta muito os times daqui, os times que são brasileiros. Todo Mundo de lá! Quase que a maioria, porque, quando o seleção brasileira tá jogando todo mundo tem de ter onde assistir. Assistir o jogo. Ali quando o time ganho, fica uma festa lá, todo mundo. Ali quase todo mais, todo mundo, a gente queria ver mais por aqui, que sabia que aqui tem o futebol melhor [...] Pra trabalhar, e gente (pausa) na primeira emprego que tinha, é só entrar numa loja, que chama "Lojão dos Parafusos", ali, eles me deixaram no depósito, a trabalhar lá, mas como a gente é profissional, ele (pausa) me contratar como profissional, mas me deixar no depósito e me pagou como todo mundo de lá, mas isso eu não gosto não! Por isso eu saí de lá! [...] Sim tenho minha esposa e uma filha. Ela tem quatro anos [...] Ah!, então isso é uma coisa estranha (risos), porque você não tem amigo, não tem, não tem amigo e não fala o idioma é (pausa) muito estranho, mas porque o mais importante é que o brasileiro é muito hospitaleiro. Isso é o mais importante. Pessoa da igreja, mesmo que a gente não fala muito, mas ele receber com muita alegria. Ali ele faz amizade e ajudar a gente (GERLIN, 28/04/2013).

Esse trecho de entrevista é bastante significativo, pois nele o narrador discorre sobre as razões que o levaram a escolher o Brasil como rota de imigração, fala das expectativas criadas sobre os brasileiros, sobre as relações de amizade e dos descontentamentos construídos no Acre. Assim como na narrativa de Tervenkus Petit, Guinot Gerlin estabelece a ligação entre auxílio e amizade evidenciando os critérios adotados por ele para tecer considerações a respeito das relações de trabalho e com aqueles que denomina "amigos". 
Para Guinot Gerlin, a presença de algum conhecido poderia amenizar o estranhamento experimentado nos primeiros contatos que estabeleceu na capital do Acre. Não ter "ninguém aqui em Rio Branco" é uma dificuldade a mais no processo de adaptação ao novo ambiente. Dificuldade suavizada através do encontro com "um amigo". Essa "amizade" parece indicar muito mais o auxílio que esta pessoa lhe teria prestado do que um possível reencontro com algum rosto familiar.

Ainda sobre este tema, as "várias amizades" feitas por Guinot Gerlin, principalmente com membros da Igreja Adventista do Sétimo Dia, frequentada por ele, são elencadas em meio às práticas religiosas, convites, participação em visitas e passeios, mas, fundamentalmente, elas são caracterizadas pela ajuda oferecida, seja no "alugar uma casa pra morar", no conserto do encanamento defeituoso ou simplesmente na ajuda oferecida "da maneira que eles pode".

Urge pontuar que tanto para Tervenkus Petit quanto para Guinot Gerlin, a orientação religiosa se apresenta enquanto elemento fundamental no que diz respeito às relações de trabalho e, esta última, desempenha importante papel na escolha de quem é ou não "amigo". A sociabilidade estabelecida a partir do labor vinculado à observação de regras, dias e horários especiais relacionados à prática religiosa, é orientada para o reconhecimento daqueles que não "fala mentira" e os tratam "como profissional".

Ao discorrer sobre suas primeiras experiências de trabalho em Rio Branco, Guinot Gerlin julga os procedimentos adotados por patrões ligados à esfera pública e privada e lhes dá o veredito apontando o que "não era bom" e, ato contínuo, pela saída da empresa em que o tratamento desagradasse. Este gesto significativo, pautado na interpretação do vivido, lança por terra os discursos humanitários que oferecem a mão de obra haitiana a um preço baixo sob a prerrogativa do auxílio ou da solução de seus (próprios?) problemas.

Guinot Gerlin estabelece uma diferenciação entre os patrões que "fala mentira” ou que o contrataram como profissional, mas o "deixaram no depósito, a trabalhar lá" e ainda o pagavam "como todo mundo de lá" e os brasileiros que seriam "hospitaleiros" e "prestativos". Nesta aparente contradição, afinal os maus patrões eram também brasileiros, Guinot Gerlin retoma a associação entre auxílio e amizade, desta feita, separando "brasileiros" de exploradores. É óbvio que este não é um posicionamento imutável, o tempo e as permutas sociais podem conferir outras interpretações a respeito dos indivíduos com quem ele se relaciona. O próprio Guinot Gerlin, já aponta essa possibilidade de mudança no que tange à interpretação ao afirmar que não "tem amigo", no entanto, "o brasileiro é muito hospitaleiro".

Ocorre, neste momento, uma espécie de "blindagem" em relação ao "brasileiro", que é representado como alguém que vive no "país do futebol", esporte apreciado no Haiti e importante instrumento de intervenção cultural brasileira naquele país. $\mathrm{O}$ acompanhamento das partidas disputadas por times e, principalmente, pela Seleção Brasileira de futebol, fornece os materiais necessários para a elaboração de uma representação acerca do "Brasil” e dos "brasileiros". Daí o desejo de Guinot Gerlin de se dirigir ao Brasil, porque sabia que "aqui tem o futebol melhor". As festas proporcionadas pelas vitórias da seleção do Brasil são associadas à receptividade do "brasileiro", que os "receber com muita alegria".

Como afirmamos, essas representações sofrem alterações, uma vez que estão intimamente relacionadas às sociabilidades estabelecidas entre e pelos sujeitos que as elaboram em "um tempo saturado de 'agoras"' (BENJAMIN, 1987, p. 229). Neste sentido, as trocas e mediações ocorrem em todas as direções e incidem nas formas de interpretação do real vivido pelos sujeitos que o experimentam e discorrem (com gestos e palavras) sobre ele. Daí o "mais ou menos" atribuído por Guinot Gerlin, ao seu primeiro contato com Rio Branco comparado à imagem que já havia construído a respeito do que seria o Brasil.

É importante acentuar que essas trocas não ocorrem isonomicamente, existem, nunca 
é demais dizer, entre os elementos em contato, componentes (espaciais, temporais e situacionais) que tornam privilegiada a situação de um ou de outro participante dessas interações; deste ou daquele sujeito envolvido nos processos de mediação cultural e as associações se dão em consonância com o valor posicional assumido no interior dessas relações, como pontua Stuart Hall:

Há notável variação, tanto em termos de compromisso quanto de prática, entre as diferentes comunidades ou no interior das mesmas — entre as distintas nacionalidades e grupos linguísticos, no seio dos credos religiosos, entre homens e mulheres ou gerações. Jovens de todas as comunidades expressam certa fidelidade as "tradições" de origem, ao mesmo tempo em que demonstram um declínio visível em sua prática concreta. Declaram não uma identidade primordial, mas uma escolha de posição do grupo ao qual desejam ser associados (HALL, 2003, p. 66).

Nessa citação, torna-se evidente o conteúdo político das escolhas identitárias, que emerge da aspiração de pertencimento a um grupo em dado momento ou da negativa dessa associação em virtude de mudanças no contexto. Alternativas construídas a partir da reflexão sobre as implicações decorrentes de se constituir ou não em membro de determinada comunidade associativa.

Nas narrativas dos e produzidas sobre os imigrantes haitianos, estas escolhas identitárias também se fazem presentes, tanto no que concerne à busca por uma associação com os "despossuídos" provenientes do Haiti, quanto à negação ou afastamento em relação a essa identificação. O primeiro caso muito mais frequente entre aqueles que ainda não conseguiram a documentação necessária para a permanência e/ou trânsito no território brasileiro. No que se refere ao segundo posicionamento, o identificamos com maior facilidade nas falas daqueles que já conseguiram certa estabilização no Brasil (alguns chegam a se esconder quando percebem a aproximação de algum haitiano).

Eles nos procuram achando que podemos ajudar, mas não podemos e acabamos ficando mal. Não gosto quando me veem trabalhando aqui porque eles vêm me pedir ajuda e o patrão pode não gostar. Atrapalha o serviço e não posso fazer nada por eles (JEAN PIERRE, 02/04/2012).

Nesta fala de Fernando Jean Pierre, haitiano, 24 anos, agricultor, que no momento se apresentava como auxiliar de pedreiro, o "nós" e o "eles" são reconfigurados para marcar diferenças em relação a uma certa situação de estabilidade do enunciador. Ele não chega a negar a proveniência haitiana, mas se percebe em posição diversa daqueles sobre os quais discorre. É a impossibilidade de prestar auxílio, somada ao medo de ser malvisto no ambiente de trabalho que, segundo o próprio narrador, o faz se posicionar deste e não de outro modo em relação a seus patrícios.

Fernando Jean Pierre, pensa sobre sua condição e rapidamente articula as possíveis leituras feitas por aqueles que provavelmente vão lhe pedir auxílio e as virtuais interpretações efetuadas por esse "outro", o patrão, que o recebeu como trabalhador assalariado. Além disso, avalia nossa posição de observador e articula uma justificativa para seu modo de agir perante aqueles que, para nós, estariam na mesma condição que o narrador. Sua resposta é a manifestação de todas essas nuances pesadas e sopesadas na conjunção entre práxis e léxis.

Isso nos faz problematizar as posições do observado e do observador. Quem faria o que na situação descrita? A observação é mútua e as atitudes são elaboradas a partir do julgamento político em relação ao outro. Não há aqui “designação" (HALL, 2003, p. 63), os fazeres e os dizeres são traduções orientadas por esse misto entre prática e discurso que conforma aquilo que chamamos realidade (HALL, 2003, p. 364).

A situação descrita corrobora as análises feitas por Mary Louise Pratt (1999), no que tange às práticas de apropriação, tradução e enunciação levadas a cabo por indivíduos que experienciam situações sociais assimétricas, mas que em meio a essa assimetria, produzem significados para reinterpretar a si no diálogo com a alteridade, dando mostras do quanto a presença desse outro é importante, pois 
é a partir dela, que (nos) problematizamos e produzimos a nós mesmo(a)s.

Orientado por uma prática discursiva que o "eleva” a uma precária situação de estabilidade através do trabalho, o entrevistado se apresenta reticente quanto àqueles que, segundo seu julgamento, ainda não adquiriram a condição de "quase integrado". Notemos que esse "quase" não denota uma provisoriedade das situações vivenciadas, ele (o quase) figura como situação de permanente insegurança, cuja superação é depositada em um futuro "mais ou menos" distante e que, como "tempo vindouro", ainda não chegou. A maior proximidade em relação a esse futuro almejado e sempre adiado é figurativamente alcançada pela ótica do trabalho, entregue como primeira comprovação de valor e merecimento de uma (sub)cidadania, a meio caminho da cidadania plena que, como dissemos, não chega.

De modo semelhante, o "nós" e o "eles" também podem ser questionados no que concerne às práticas culturais. Ao narrar o exotismo de uma ação inscrita no interior de "uma" cultura, indicamos a distância que existe entre ela e "nossas" práticas culturais. Ao mesmo tempo, quando dentro do conjunto dessas "práticas estranhas", localizamos e valorizamos aspectos semelhantes àqueles que julgamos inerentes à "nossa própria cultura", pressentimos ou reconhecemos (não sem conflitos) um elemento fundamentalmente relacionado a toda formação cultural: a "crioulização" (GLISSANT, 2005).

Pensar as articulações entre indivíduos provenientes do Haiti, suas atitudes e presenças enquanto enunciações, assim como as narrativas elaboradas por essas pessoas, nos permite questionar muito mais do que explicar essas trocas estabelecidas entre indivíduos temporalmente inscritos em uma dada realidade social (CALDEIRA, 1991). Figura nas narrativas coletadas uma relação muito atual com o país de ingresso, ao mesmo tempo, um traço vinculante entre as causas da dispersão e as possibilidades de retorno à terra natal. Esse retorno, em um primeiro momento, se faz representar pelo envio de notícias e/ ou recursos para ajudar familiares que permaneceram no Haiti. A estadia em solo brasileiro é vista como provisória, pois a vontade é de poder conseguir um trabalho que propicie regresso o mais brevemente possível.

Como nos contou Kesnel Theodule, haitiano, trabalhador agrícola de 23 anos, que em janeiro de 2012 se identificava como pedreiro, em uma conversa que tivemos e gravamos durante um almoço em uma pensão nas proximidades da praça Hugo Poli, no centro de Brasileia: "cinco anos é muito tempo, não podemos ficar tanto tempo assim, porque nossa família ficou lá. Temos que trabalhar para voltar, no máximo em um ano ou dois, não aguento mais que isso!".

Os cinco anos aos quais Kesnel Theodule se refere, são os fixados como máximo permitido para aqueles que tiveram o pedido de refúgio realizado junto ao e indeferido pelo Comitê Nacional para Refugiados (CONARE), que trata da concessão de permanência aos imigrantes no Brasil. Durante esse período, eles utilizarão um visto humanitário que lhes dá o direito de ter CPF, Carteira de Trabalho e utilizar os serviços públicos de saúde. Após esse prazo, eles deverão demonstrar que estão trabalhando e estabelecidos no país se desejarem aqui permanecer, caso contrário, devem ser "repatriados".

O desejo de permanecer por apenas "um ano ou dois" confirma a percepção do Haiti como o lugar de "destino", que deve, à medida que os emigrados alcancem sucesso em suas empreitadas, ser reconstruído, possibilitando-lhes o regresso. O trabalho no Brasil, nesses enunciados, subjaz como o meio necessário para alcançar este fim.

Não podemos deixar de anotar que, para muitos estrangeiros haitianos, senegaleses, dominicanos no Brasil, esta é mais uma das diversas tentativas de melhoria nas condições gerais de vida a partir da imigração. Suas experiências dentro e fora das Américas nos dão mostras do lugar que, apesar das enunciações conciliatórias e acobertadoras, tem sido reservado aos pobres de "todas as cores" neste nosso mundo moderno. Eternamente deslocados e reduzidos (discursivamente) à condição de força de 
trabalho, números estatísticos e/ou matéria de jornais, essas pessoas se tornam "quase abstrações" maleáveis pelas práticas discursivas recorrentes nesses textos.

"Refugiados do Haiti vão para Rondônia trabalhar em usinas" (Estelita Hass Carazzai -Folha
de São Paulo - 10/03/11); "Haitianos refugiados conseguem emprego no AM, RO e AC"
(Estelita Hass Carazzai, Fábio Freitas e Kátia Brasil - Folha de São Paulo - 14/03/11);
"Refugiados haitianos buscam Brasil por emprego" (Edson Luiz - Correio Braziliense -
15/03/1); "Firma de Santa Catarina vai a Brasileia para contratar haitianos" (Marcelle
Ribeiro - O Globo -05/01/11); "Especialistas: crescimento do Brasil atrairá novos
imigrantes" (Flávio Freire - O Globo -11/01/12); "RS vai receber haitianos para trabalhar
em fábrica" (Rossana Silva - Zero Hora - 11/01/12); "Conselho Nacional de Imigração
cria visto especial de trabalho para haitianos" (Daniella Jinkings - Agência Brasil EBC -
12/01/12); "Empresas gastam até R\$ 1 mil para importar mão de obra haitiana do Acre"
(Dubes Sônego - Portal iG - 01/02/12); "Haitianos chegam ao interior do Paraná para
suprir falta de mão de obra" (Amanda de Santa - Jornal de Londrina - 08/02/12); "Mega
obras facilitam inserção de haitianos" (Mario Osava - Envolverde/IPS - 22/03/12).

Enunciados como esses podem ser facilmente encontrados nas páginas de jornais e pronunciamentos de autoridades ligadas às esferas federal, estadual e municipal, produzindo e difundindo narrativas em que a preciosa mão de obra haitiana pode ser amplamente explorada sob a alegação de que se está agindo com finalidade humanitária. Sem qualquer menção às causas do espalhamento haitiano, ou apenas com pequenas referências a essa questão, essas pessoas são (discursivamente) reduzidas a força de trabalho que pode ser "importada", "inserida", "recebida" para "suprir" carências de empresários e empresas, no que concerne ao desenvolvimento de seus negócios, por todo o território nacional.

Neste sentido, torna-se relevante perceber como antigas e novas formas de expropriação, que se entrelaçam para compor alguns dos elementos das diásporas (passadas e presentes), subjazem nesses enunciados e se mostram com todo o vigor na diáspora haitiana. Exemplo disso foi o episódio divulgado em reportagem veiculada pelo jornal Gazeta em Manchete, do dia 25 de janeiro de 2012, cuja chamada de matéria foi realizada pela apresentadora do programa nos seguintes termos:

Em Brasileia, empresas de Rondônia contratam haitianos para trabalhar na construção civil. Até aí tudo bem, só que tem um detalhe: eles escolhem os haitianos de acordo com a canela! É isso mesmo, de acordo com a canela. De acordo com os contratantes quem tem canela fina é trabalhador e quem tem canela grossa...

Destaca-se desse texto, não o vínculo estabelecido entre as formas de seleção dos "futuros trabalhadores" e os métodos implementados nas "feiras da carne" organizadas para a compra e venda de escravos por toda a América entre os séculos XVI e XIX, mas o inusitado de se escolher "haitianos de acordo com a canela!". A presença desse "inusitado" não esconde a naturalidade com que era visualizada a redução daqueles seres humanos a mera mão de obra disponível às empresas de Rondônia e de outros estados do Brasil. O "até aí tudo bem", enunciado pela apresentadora, nos comunica a "normalidade" da procura e do "encaminhamento" dessa "mão de obra" no mercado nacional.

Na sequência da matéria, um repórter discorre sobre a chegada dos haitianos ao Acre e diz que "com a ajuda humanitária recebida, centenas deles cruzaram nossas fronteiras". Essas afirmativas fazem parte do material que enreda determinada perspectiva de auxílio humanitário, pautado pela inserção dos haitianos (estrangeiros) em uma (sub)cidadania em "nossas fronteiras", através de uma narrativa que justificaria a hierarquização entre grupos humanos. Ao continuar sua fala, o repórter diz ainda que "O drama vivido pelos haitianos repercutiu na imprensa nacional e atraiu empresários de vários estados em busca de mão de obra, principalmente para a construção civil’. Essa enunciação, junto ao comentário de um representante da Secretaria de Direitos Humanos do Acre, nos dá evidências da forma como esses seres humanos são "levados" para outros estados. Isso desvela não apenas uma tentativa de privar de 
vontade um conjunto de seres humanos, mas também a concordância popular com essas práticas, uma vez que "é o apoio do povo que confere poder às instituições de um país" (ARENDT, 2009, p. 57).

Ainda em relação à reportagem, o próprio contratante indicava naquele momento as referências adotadas por ele para efetivar a seleção de trabalhadores, segundo ele, a "técnica" seria uma "tradição antiga, de pessoal da escravidão. Quem tem canela fina é bom no trabalho; canela grossa é mais ruim de serviço". A imagem do contratante negro selecionando trabalhadores também negros utilizando-se de critérios do "tempo da escravidão" sob a égide do auxílio humanitário, além de lançar os não selecionados para "fora da humanidade", também encerra (discursivamente) os "escolhidos" em um nível de humanidade pré-determinado pela compleição física, indicando que alguns seriam, "por natureza", menos humanos que outros.

Não obstante essas tentativas de eliminação de vontades e de silenciamento de opiniões, como Hannah Arendt (2007, p. 330) nos convida a refletir, esses sujeitos passam também a dizer de si, a partir desse lugar-comum da força de trabalho, mas, ao recorrer a esses enunciados redutores, eles buscam reafirmar sua humanidade real, re-significando e invertendo os sentidos do que é dito na tentativa de lhes reduzir a mera mercadoria. E fazem isso a partir de outras experiências e referenciais. Com este propósito, vemos emergir a afirmação de uma haitianidade inventada no deslocamento e apresentada na oposição/comparação entre brasileiros e haitianos, repetidamente enunciada nos dizeres recolhidos junto a esses indivíduos. Essas enunciações reivindicam o reconhecimento, ao mesmo tempo, das diferenças entre brasileiros e haitianos e exigem igualdade, pois estariam todos inscritos no campo da humanidade.

Da presença física e enunciativa de sujeitos com corpos negros nesta parte da Amazônia Sul-Ocidental, vemos emergir a outra face da racionalidade moderna, que organiza o tempo, fende e hierarquiza culturas. Como nos ensina Maria Antonieta Antonacci, esses sujeitos subvertem "a pauta do possível", fazendo-se vistos e ouvidos; "expondo intimidades de agressões seculares e assumindo latências político ideológicas” (ANTONACCI, 2013, p. 240). Procuram um lugar mais justo no enredo que conforma este Ocidente, que sustentaram e sustentam com o suor e sangue de seus corpos negros; rompendo e re-significando distâncias, unindo isto e aquilo, exigem continuar sendo seres humanos.

Estar no Brasil (como imigrante haitiano) representa essa reelaboração de sentidos, a luta permanente para permanecer enquanto seres humanos e, em meio aos embates concernentes a esse anseio, não apenas uma relação íntima com o Haiti é elaborada, mas também é construída uma nova leitura de trajetória a partir do momento presente (SARLO, 2007). Aí está inscrita a percepção de se estar provisoriamente em solo estrangeiro, e, por isso mesmo, cogita-se um retorno à "terra natal", lugar de justiça e igualdade cuja palavra "destino" é o referencial.

Assim como na narrativa hebraica do Antigo Testamento, é durante o Êxodo que são estabelecidas as leis (escritas) e os códigos que fornecerão a base identitária para a constituição do "Povo Escolhido". É ali, entre o partir e o chegar que se recupera a imagem da "Terra Prometida"; que se estabelecem os laços entre aqueles que devem, um dia, dirigir-se novamente para lá. Todas as "provações" experimentadas no caminho são relidas a partir do momento presente e re-significadas com base na situação atual dos narradores (BENJAMIN, 1987) e/ou daqueles que se identificam com aquelas narrativas.

Dentre os haitianos que lograram alcançar o território brasileiro, a narrativa daquilo que ocorreu no translado adquire a forma de odisseia finalizada. Não que os haitianos se pensem como partícipes e partidários de uma disputa épica entre o pensamento lógico e o poder dos deuses (ADORNO \& HORKHEIMER, 1985, pp. 53-80), tema da Odisseia de Homero (sec. VIII a.C.), mas eles elencam as distâncias e as dificuldades superadas como feitos grandiosos que serviriam como prova de obstinação e vontade de trabalhar; uma espécie de título inserido ao Curriculum Vitae desses indivíduos. 
A distância existente e insistentemente anunciada entre o Haiti e o Brasil não é apenas o espaçamento físico entre um e outro país, e o deslocamento enunciado não é mero translado. A despeito de ser toda odisseia também uma viagem, compreender que nem toda viagem é, em si, uma odisseia torna-se relevante para o entendimento da função que o relato das dificuldades desempenha nas narrativas dos sujeitos desta pesquisa. O simples deslocamento não produz as extraordinárias histórias (nem sempre felizes) narradas pelos imitadores de "Ulisses". Odisseu enfrentou seus desafios ao retornar de Tróia para Ítaca, mas talvez seus companheiros nunca tivessem sabido do que lhe ocorrera caso ele não tivesse chegado e também vencido os perigos que lhe esperavam em casa. Seu triunfo foi cantado como o fim glorioso de uma eloquente coleção de aventuras elencadas no encadeamento de um destino já traçado. No entanto, como nos ensina Walter Benjamin (1987), esse destino só foi reconhecido a partir do olhar voltado a um passado elaborado e narrado, considerando primordialmente aquilo que parecia relevante para a construção do que fora alcançado no instante em que se narra (SARLO, 2007).

Se o desfecho fosse outro, talvez o passado também fosse contado de forma diferente, pois a ideia de destino é construída no presente, a partir da relevância que o fato narrado assume no (e para o) momento atual, na elaboração do enredo que compõe a narrativa. "Seria preciso distinguir conforme as épocas, e ver como as decepções transformam as representações originais" (PERROT, 1988, p.115). Se Ulisses não tivesse voltado a Ítaca, sua história teria outro final, localizado, talvez, naquele lugar que para nós se encontra "no meio" de suas aventuras. Neste caso, o destino seria meramente "aquilo que aconteceu com ele" e não o que lhe estava, desde o início, "reservado".

Nas entrevistas realizadas e enunciações coletadas, encontramos relatos que tratam o trajeto do Haiti ao Brasil tanto como viagem, quanto como odisseia (transcurso e vitória em relação aos obstáculos do caminho). Essas narrativas, como não poderiam deixar de ser, adquirem formas diferentes em decorrência das experiências vivenciadas pelos sujeitos durante o trajeto, mas também ganham novos contornos a partir do "destino" alcançado; da recepção direcionada aos que chegam; dos discursos que se estabelecem a respeito dos recém-chegados. É a partir do ponto de chegada que se organiza o que é "necessário" lembrar, é aí que ocorre a valorização de determinados aspectos do percurso em detrimento de outros, neste lugar se constroem as narrativas e, dentre elas, as identidades (RICOEUR, 1994).

Não emigramos porque queríamos emigrar de nosso país! Não saímos do país porque queremos!
Saímos de nosso país, de nossa amada pátria, porque tivemos que sair, porque não tem, não há
trabalho! É um país defo, devastado: terremoto, furacões e uma má gestão do governo! Por isso os
haitianos saem, não saem “por assim, por assim”! Graças a Deus temos chegado em muitos países
onde temos dado prova de que sim, o haitiano é uma pessoa honesta, uma pessoa trabalhadora, sai
de seu país para trabalhar, para progredir e juntamente com esse progresso, o haitiano também, com
seu labor, ajuda a comunidade a progredir juntamente com ele! (JOSEPH, 18/04/2011).

Neste trecho significativo, podemos perceber a valorização das dificuldades e dos perigos do caminho (destacados em diversas outras falas), não apenas como enumeração da ocorrência destes, mas como valorização do próprio narrador, que, por ter vencido tais obstáculos, se mostra obstinado, corajoso, mas também trabalhador e, no momento, necessitado.

Leonel Joseph incorpora e traduz os discursos elaborados que tentam enquadrá-lo e aos demais haitianos como sujeitos sem vontade, utilizando essa tradução para afirmar exatamente o contrário disso. Ao elencar as causas da dispersão haitiana: escassez de trabalho, devastação, "terremoto, furacões e uma má gestão do governo", ele discorre sobre a ausência de um querer quanto à imigração, concomitantemente, elenca as razões que os levaram a "optar" pela saída do país, evidenciando o quanto desta "escolha" está fundamentada na leitura e interpretação do vivido. Apesar de não terem emigrado porque "quiseram", “quiseram” emigrar porque necessitavam. Revisitando essa experiência através dos trabalhos da memória (BOSI, 1998), ele afirma que "Saímos de nosso país, de nossa amada pátria, porque 
tivemos que sair"”.

Em uma perspectiva que se aproxima das proposições feitas por Paul Ricoeur, visualizamos na narrativa de Leonel Joseph, o entrecruzamento de diversas articulações que colaboram para a conformação de uma trajetória individual no diálogo com o coletivo. Essas articulações são compostas por escolhas feitas com base na reflexão, mas também são frutos de acasos que se entrelaçam em determinados espaços e tempos (que são também narrativas), tornando única cada experiência.

Do relato de Leonel Joseph, destacamos a compreensão de que nem sempre fazemos nossas opções baseados apenas em nossa própria vontade (se é que alguma vez agimos assim) e, inspirados por Ricoeur, inferimos que não podemos ter o controle sobre todas as implicações decorrentes dessas escolhas, o que nos leva a refletir sobre as possibilidades de exercício de nossas liberdades individuais e as relações estabelecidas entre o en e o outro (indivíduos, cultura, sociedade, etc.), eixo central para a construção incessante das narrativas identitárias. Sujeito e objeto nesta reflexão não estariam separados, apesar de estabelecerem relações assimétricas entre si, atuam como interlocutores.

Ao discorrer sobre aquilo que chama de "prova", Leonel Joseph, responde a um questionamento lançado por um interlocutor oculto, mas hierarquicamente localizado acima, posto que tem a possibilidade de questionar as capacidades dos imigrantes no que concerne ao trabalho e às suas intenções no Brasil. A fórmula "Graças a Deus, temos chegado em muitos países onde temos dado prova de que sim (...)", utilizada pelo narrador, expõe tanto esse interlocutor quanto seu questionamento. A resposta formulada pelas ações (interpretadas e descritas) desse sujeito evidencia o reconhecimento dessa autoridade (do interlocutor) e uma tentativa de reposicionamento, no interior da interlocução, daquele que responde, "com seu labor" e com suas palavras, ao questionamento lançado.

A resposta afirmativa apresentada pelo narrador exige o reconhecimento de que "o haitiano é uma pessoa honesta, uma pessoa trabalhadora, sai de seu país para trabalhar" e propõe a igualdade entre os interlocutores, exigindo o reconhecimento do imigrante enquanto membro daquilo que Leonel Joseph denomina de "comunidade", uma vez que ele veio "para progredir e juntamente com esse progresso, o haitiano também, com seu labor, ajuda a comunidade a progredir juntamente com ele".

Leonel Joseph, fala fluentemente várias línguas, e orgulha-se deste fato. Orgulho presente no olhar que dirige à câmera quando discorre sobre sua experiência como professor e durante a enumeração dos idiomas dominados por ele. A condição de "coitado" ou miserável pode até ser utilizada para se fazer ouvir, mas está distante da maneira como ele enxerga a si e aos demais haitianos.

Sim, os que chegaram primeiro, depois do terremoto, entraram sem problemas, na fronteira em Inãpari, sem problema eee já muitos deles já estão traba, traba, trabalhando no Brasil, estão desempenhando seu labor como pessoa humana. Os haitianos somos pessoas muito trabalhadoras, em qualquer país que chegamos nós, se reconhece que os haitianos trabalham, por isso ao chegar ao país do, do Brasil, damos prova contundente de que somos trabalhadores. Muitos estão trabalhando em Manaus, estão trabalhando em Minas Gerais, Rio de Janeiro eee muitos também estão em Rio Branco, Porto Velho. Muitos haitianos estão trabalhando em território brasileiro de maneira legal, de maneira digna (JOSEPH, 18/04/2011).

As vitórias sobre os empecilhos do caminho são apresentadas como "provas contundentes" de sua (deles) vontade/coragem de trabalhar não apenas em causa própria, mas de suas famílias que permaneceram no Haiti e da comunidade encontrada nos países de ingresso. Leonel Joseph escolhe muito bem as palavras para construir seus enunciados e conscientemente relaciona as adversidades transcorridas a uma valorização daqueles que lograram adentrar o território brasileiro. Certificação, segundo suas concepções, de capacidade e merecimento dos ingressantes.

Destaque-se deste ponto da narrativa a apresentação do trabalho como norteador da 30 elaboração do mérito que o narrador quer comprovar. Nas palavras de Leonel Joseph, o labor é pressu- 
posto para a aquisição da dignidade desejável a todo ser humano. Com base no tratamento direcionado aos haitianos, ele formula uma interpretação em que apenas a alegação de que "somos todos humanos" não é suficiente. Seria necessária uma "prova" de outra ordem, baseada no "labor", na "honestidade" e na vontade de "progredir junto à comunidade".

Uma vez tratados como simples números em estatísticas, ou oferta de mão de obra que serviria de motor para empresas de todas as nacionalidades inseridas nos países percorridos por esses homens e mulheres, esses sujeitos passam também a negar/assumir (CHAUÍ, 1986) tal identificação. Negam, pois compreendem sua humanidade como inalienável, daí o próprio sentido da imigração, permanecerem sendo homens e mulheres. Assumem, pois percebem que é a partir da apropriação dos discursos elaborados pelos outros que poderão alcançar a inserção que lhes garantiria pleitear a igualdade, segundo as palavras de Leonel Joseph, necessária ao reconhecimento de que eles não perderam ou devem ser repostos na condição humana.

No diálogo com os discursos que se reproduzem a respeito dos haitianos, estes últimos reelaboram e produzem novas narrativas para dizer de si. Ao negar/assumir (CHAUÍ, 1986) a condição de mão de obra, pleiteiam eliminar as possíveis justificativas para sua exclusão. Por outro lado, ao buscar a superação desta situação através do labor (que eles já executavam antes de emigrar) acabam também se reduzindo àquilo que os tratamentos instaurados sobre eles visavam desde o início. A desumanização serviria para torná-los “dóceis" para o trabalho mal remunerado destinado aos "não integrados” e estes, se afirmam a partir do labor na tentativa de demonstrar ou reivindicar suas permanências na condição humana.

Eu sou Fernand, Fernand Jean Píerre, saímos do Haiti e fomos à República Dominicana. Chegamos,
compramos passagens para viajar ao Peru, capital Lima para visitá-lo como turistas. Compramos
as passagens por quarenta e nove mil pesos para chegar ao Peru. Porque tínhamos que sair para
visitar e quando chegamos ao Peru cruzamos para chegar aqui ao Brasil. Porque tínhamos, quando
aconteceu o terremoto perdemos tudo o que tínhamos, casa, perdemos dois primos que morreram
e chegamos aqui para trabalhar e ajudar nossas famílias que ficaram no Haiti, porque a situação não
está muito bem, muito boa. Chegamos aqui para conseguir trabalho para ver o que se pode fazer, se
volta a construir a casa ou ajudar nossas famílias. Já temos um mês aqui no Brasil, já temos! JEAN
PIERRE, 31/01/2012).

Nessa passagem, o "trabalho redentor" novamente norteia as perspectivas de retorno e o sentimento da diáspora (HALL, 2003) se faz presente nas palavras de Fernand Jean Pierre. Este retorno, em um primeiro momento, se faz representar pelo envio de recursos para ajudar familiares. A vontade é de poder "conseguir trabalho para ver se volta a construir a casa".

A viagem do Haiti ao Brasil; as dificuldades encontradas no trajeto; o encontro com outros que partiram há mais tempo e ainda não conseguiram alcançar seus objetivos; a busca pelo ingresso no Brasil e a coesão estabelecida entre membros dos grupos de imigrantes como forma de proteção nesse "novo lugar", fomentam uma formação discursiva na qual o Haiti não é apenas o lugar de onde se partiu, mas também o ponto para onde se deve retornar para reconstruir aquilo que se perdeu. No entanto, essa reconstrução aparece como idealização, posto que o Haiti do qual falam e do qual se lembram, também o é. Semelhantemente, ao refletirmos sobre a questão identitária, enfocamos as enunciações que se fazem a partir das e pelas ações de nossos sujeitos da pesquisa, de sua práxis e sua léxis, como materialização daquilo que desejam para si e para o mundo, expressões de um dado momento inscrito em um determinado espaço constitutivo de uma certa identidade pensada por Paul Ricoeur (1994) como narrativa.

Seguindo essa orientação, podemos afirmar que não há inocência nos atos (palavras e ações) de um sujeito no mundo. Todos esses atos indicam interesse e uma determinada orientação do pensamento sobre si e sobre aquilo que o cerca, é performance (BUTLER, 1990) e denota identidade. De 
acordo com Paul Ricoeur (1994), a função narrativa estaria então na base constitutiva da elaboração identitária, seja dos indivíduos ou das coletividades, pois ela atuaria como ponto de inteligibilidade unindo história e ficção.

Representações que emergem das fissuras abertas em espaços de negação do direito à vOz e à participação, em uma perspectiva muito próxima daquilo que Maria Antonieta Antonacci discutiu ao analisar as manifestações artísticas produzidas na articulação entre cultura e diásporas. Para ela, essas manifestações permanecem "insinuando-se em fronteiras, articulando o semelhante à diferença, suas inesperadas performances configuram-se em fatigante trabalho de romper brechas, tornar visíveis e audíveis lugares de memória entre o gesto e a voz" (ANTONACCI, 2013, p.14).

A ação de migrar e as representações construídas nesse e sobre esse trânsito, são referentes às tentativas de fazerem-se vistos e ouvidos na união entre gesto e palavra. Nesse sentido, a ideia de um "destino" apresentada nas narrativas identitárias de haitianos no Acre, está relacionada ao espaço e ao tempo em que se narra; com as especificidades desse tempo e do espaço nos quais e através dos quais elas (as narrativas identitárias) estão sendo construídas.

O tempo da significação não é o tempo dos deuses tendo em vista ser este inacessível aos homens. Os significados são articulados no fluir profano da experiência humana, único local em que se pode exigir a verdade dos modos narrativos. O tempo posto em narrativa recebe sua significação da experiência tornada comum (SARLO, 2007) pela enunciação (presença, palavra e gesto). Os narradores são "eles mesmos" com seus nomes, suas origens, seus dramas e suas esperanças, mas também são outros, pois se tornam projeções daquilo que buscam, do "destino" que esperam encontrar na diáspora.

O "destino" é, assim como as identidades, constituído de narrativas ordenadas e orientadas por sujeitos que desejam produzir determinados sentidos a partir do ato de narrar (BENJAMIN, 1987). O encadeamento dos fatos narrados; a escolha deste ou daquele fragmento que comporá o enredo são frutos dessa busca pelo sentido, que é o próprio (no duplo sentido) processo de elaboração identitária.

A situação do "país de origem", o Haiti, assim como a dos próprios imigrantes, é apresentada como provisória e essa provisoriedade aparece nas falas de nossos narradores como dependente, em parte, do sucesso ou insucesso daqueles que imigraram. O desejo é de ajudar àqueles que lá ficaram e, fazendo isso, colaborar com a reconstrução do país. No entanto, para aqueles que já estão no Brasil há "mais tempo" (o que pode variar de acordo com as experiências individuais), o retorno físico torna-se menos evidente em suas narrativas. $\mathrm{O}$ que nos parece é que esse reencontro com a origem se torna mais simbólico que material. Fala-se agora em "naturalização", em "buscar a família", "ajudar os amigos que desejam sair do Haiti”, como fala Guinot Gerlin, pois "não se deixa de ser haitiano quando se vive em outro lugar", tendo em vista que "o Haiti está em nós”.

Com o esvaziamento das perspectivas de regresso, o retorno se faz por outra via. Nas palavras de Guinot Gerlin, são eles próprios que tomam para si a responsabilidade pela redenção da terra natal metaforizada em seus corpos e seus dizeres. Na comunicação com a família distante milhares de quilômetros do Acre, eles falam das boas condições de acolhida; de suas possibilidades de trabalho e de suas expectativas de permanência.

A consciência de que a estrutura física, política e social do Haiti não está sendo reconstruída, somada às informações provenientes do Brasil, além da piora nas condições gerais de vida das populações que permanecem na terra natal é solo amplo para o convencimento de novos possíveis emigrantes, que deverão, como os que partiram anteriormente, reconstruir o Haiti fora de lá. Para os que conseguiram trabalho no Brasil, o retorno ao país se faz pelas "boas notícias" enviadas aos que lá ficaram; pelos recursos financeiros disponibilizados e/ou pelas possibilidades de emigração de outros parentes. 
Promissão realizada a despeito das infindáveis dificuldades não comunicadas ao telefone ou através da internet, afinal (por mais que aqueles que observam digam o contrário) a situação aqui encontrada, é melhor que a deixada para trás e, na reflexão sobre essas circunstâncias, mais uma vez as identidades se deslocam. No bojo das reflexões sobre as realidades experimentadas, os sujeitos que delas participam, constituem outras narrativas identitárias (RICOEUR, 1994) para que possam "dizer de si" e posicionar-se em relação ao mundo social.

Nos últimos instantes de uma das entrevistas gravadas junto ao Haitiano Tervenkus Petit, momento em que procuramos direcionar os questionamentos buscando fazer com que o entrevistado falasse sobre suas expectativas quanto ao final do prazo exigido para a obtenção do visto definitivo e/ou de sua (dele) naturalização como brasileiro, ele nos deu mostras das formas através das quais se processam as narrativas identitárias.

\footnotetext{
Armstrong da Silva Santos_É e daqui pra nove anos, como é que tu imaginas ser brasileiro? O que é ser brasileiro pra ti?

Tervenkus Petit_ Bom, é tipo assim, não sei aqui, porque se eu, tipo, futuramente, né, com a bandeira, troco de bandeira! Quer dizer, você vai ser brasileiro, naturalizado como brasileiro. Quer dizer, você já não é mais, tem o direito de ser deportado daqui. Aí você tá aqui que nem brasileiro naturalizado! É isso que eu tô pensando um dia ser, vou, tô na lida!

Armstrong da Silva Santos_ Aí você deixa de ser haitiano por causa disso?

Tervenkus Petit_É porque todo o meu documento tá (pausa) sendo mandado debaixo da bandeira, né? Aí, quer dizer, daqui a mais tempo, nêgo vai, é (pausa) piorando né? Aí o cara vai passar por brasileiro! (risos).

Armstrong da Silva Santos_Aí vão perguntar: "Petit, o que ele é"? E o Petit vai responder o quê? Tervenkus Petit _ O Petit vai ser “O Pequeno”! (risos) (PETIT, 01/08/2013).
}

Ao perceber nossa intenção, Tervenkus Petit evitou responder sobre sua futura forma de identificação nacional; se ele se identificaria dali em diante como brasileiro ou haitiano. Ele enfatiza que não terá como deixar de se identificar como brasileiro depois de nove anos, quando terá direito ao pedido de naturalização. Todos seus documentos serão idênticos aos de todos os brasileiros e ele estará, a partir de então, "embaixo da bandeira". Estar sob a flâmula brasileira significaria, de acordo com o entrevistado, assumir a condição do "outro" no que tange aos direitos civis; deixar de ser o "outro" da legislação brasileira.

O acesso à documentação é apenas um dos rituais de legitimação identitária e Tervenkus Petit sabe disso, daí os desvios assumidos para responder àquilo que não desejava. A saída magistral elaborada por ele para as incômodas perguntas, nos permite pensar que questionamentos como aqueles somente se fazem possíveis, pois presenciamos a evidência de uma diferenciação entre o entrevistado (percebido como estrangeiro/não integrado) e o entrevistador (brasileiro/integrado). O que Tervenkus Petit assinalara em seu depoimento e que, apenas posteriormente, pudemos perceber é que quando ocorre de fato integração, questionamentos como aqueles não fazem mais sentido.

Assim, ele prefere discorrer sobre si "como sendo ele mesmo" e afirma: "O Petit vai ser 'O pequeno"'. A tradução para o português do nome originalmente em francês torna-se paráfrase de sua (dele) situação pessoal. Indica que ele é filho de alguém que tem o mesmo primeiro nome; em sinal de ancestralidade. O "pequeno" Petit se torna, então, um pleonasmo que responde duplamente, mas sem explicar em demasia.

Ao afirmar sua "pequenez", Tervenkus Petit atesta não apenas humildade, mas o fato de que ele sempre vai ser aquilo que estiver sendo quando for questionado. Corroborando as assertivas de Glissant (2005), podemos afirmar que se existe algo de puro no âmbito das culturas e das identidades, isto deve ser a mistura e o movimento, pois é a partir destes que podemos dizer não aquilo que somos, mas o que estamos sendo. Essa compreensão se torna fundamental para a reflexão sobre as narrativas identitárias 
(RICOEUR, 1994) entre nossos entrevistados: seres no mundo; produtores e produtos de si, dos outros e do que os cerca, a partir da arte de narrar (BENJAMIN, 1987).

Nossas insistentes e tentativas de criar significados - permanentes e fechados - esbarram na própria origem desses significados, que surgem "nas relações de similaridade e diferença que as palavras têm com outras palavras no interior do código da língua” (HALL, 2006, p. 40). O jogo entre alteridade e mesmidade cria a necessária instabilidade na qual estão inscritos os significados. E se as dificuldades inerentes à tradução se apresentam para praticantes de um mesmo idioma, muito mais problemáticas são essas relações para quem abruptamente é lançado para o interior de um sistema linguístico:

Quando chegou aqui, então já quando chegou, sabe que (pausa) a gente não sabia nada sobre o português, só chegou pra aprender a idioma. Mesmo assim foi (pausa), tem que dá o conhecimento da idioma pra perguntar alguma coisa sobre ali, dia, dia a dia se aprende mais sobre o país. Sim, não sabia nada de Português, só a gente fala espanhol, francês, é, inglês, mais ou menos, francês creólle, é esse idioma, mas o Português a gente não sabia nada, de Português! (...) mas éé, a idioma não é, não é (pausa) não é problema, mas a gente não fala muito, mas é a conhecimento das coisa é das profissional, da profissão é ruim mesmo! E o SENAI, agora, porque, eu saí de lá com uma diploma, mas chegou aqui, quase, todas coisa quase o mesmo, mas os termo de falar sobre as coisas é precisar o conhecimento. Por exemplo, quando a gente for encontrar com o engenheiro, ele vai falar sobre os termas mesmo da construção e a gente não sabia ou vai ficar assim, como que a gente não sabia nada. Mas, agora, é melhor porque o conhecimento de lá e daqui também vai se aumentar (GERLIN, 28/04/2013).

Neste trecho de entrevista, Guinot Gerlin se esforça para falar das dificuldades enfrentadas por ele logo após a chegada ao Brasil. Antes da entrevista informamos que, se ele preferisse, poderia falar em espanhol, no entanto, ele respondeu que falaria em português porque "precisava treinar". O resultado desse esforço é a expressão da busca por entendimento, da necessidade de conhecer a língua do outro "pra perguntar alguma coisa sobre $[\mathrm{o}]$ dia a dia" e ver "se aprende mais sobre o país", evidenciando, na forma da enunciação, as dificuldades vivenciadas por ele.

Forma e conteúdo estão aí imbricados (FISCHER, 1977). Ao organizar sua narrativa para elencar os problemas experimentados, Guinot Gerlin elabora uma construção que é a expressão desses problemas. Unindo a maneira de dizer àquilo que se diz, ele duplica os significados, transformando a narrativa em muito mais que um "treino". Falar, neste sentido, é "ato performativo" (BLUTER, 1990), pois a enunciação (forma e conteúdo) produz significados sobre o que se tenta dizer, e, ao mesmo passo, sobre aquele que enuncia.

Ao enumerar as línguas dominadas para falar daquela que ele não domina, Guinot Gerlin contesta a ideia que, segundo ele, se tem de que quem não fala a língua local "não sabia nada". A enumeração dos idiomas e dos "níveis de fala" organizados por ele em uma escala que vai do "falar", passando pelo "falar mais ou menos" até o não "saber nada de português", evidenciam os conhecimentos adquiridos, aprendizado realizado também em função do trânsito pelos países em que ele trabalhou.

$\mathrm{Na}$ narrativa de Guinot Gerlin, língua e trabalho estão relacionados, pois nessa elaboração, o idioma em si não seria o problema e sim o conhecimento dos termos utilizados na profissão que "é ruim mesmo". A certificação profissional obtido na República Dominicana, não tem serventia se o narrador não consegue realizar a tradução dos termos (que já são traduções para uma linguagem técnica) para executá-los profissionalmente em um novo contexto. O curso oferecido pelo SENAI, representa essa possibilidade de tradução e a consequente atuação como profissional que poderá repercutir nos valores recebidos em função do trabalho realizado, "porque o conhecimento de lá e daqui também vai se aumentar". É interessante visualizar neste momento da fala, a compreensão que Guinot Gerlin tem da aquisição do idioma como acréscimo e não como uma restrição mediante a exclusividade linguística. Ele compreende a tradução enquanto algo que junta o "de lá" e o "daqui" em uma perspectiva muito seme- 
lhante àquilo que Édouard Glissant defende afirmando a necessidade do outro para a autocompreensão, pois eu "falo contigo na tua língua e é na minha que te compreendo" (GLISSANT, 2011, p.105).

Outra fala que pode ser problematizada quanto às formas de tradução e suas significações é a de Fernand Jean Pierre, pela intrigante relação identificada por ele entre língua e posse em uma perspectiva diferente da apresentada por Guinot Gerlin.

\begin{abstract}
Nós que falamos espanhol, conseguimos nos comunicar com um pouco mais de facilidade, temos sorte porque trabalhamos na República Dominicana e lá aprendemos a falar espanhol. Aqui em Brasileia, no Acre, as pessoas nos compreendem bem e nós, se queremos água, nos dão. Não sei como vai ser em outros locais, se em São Paulo ocorre isso. Um amigo acreano outro dia me disse que se você está com sede aqui no Acre você pode pedir água que lhe dão, mas em São Paulo se morre de sede e não lhe dão de beber. Conseguimos alguma ajuda falando em espanhol. Quem fala espanhol tem pouco, quem não fala não tem nada! (JEAN PIERRE, 31/01/12).
\end{abstract}

Fernand Jean Pierre chama de "sorte" o fato de ter trabalhado na República Dominicana. Segundo ele, aquela foi uma oportunidade de aprender o espanhol, mas seu enunciado também mostra a situação diaspórica haitiana como anterior ao terremoto de 12 de janeiro de 2010, e que a mudança para o Brasil corresponde a mais um adiamento do encontro com aquela fronteira que, uma vez transposta, guardaria a "chave da felicidade" e da vida digna. Se na primeira mudança, do Haiti para a República Dominicana, ele tivesse encontrado tudo aquilo que buscava, não haveria mais motivos pra novamente juntar recursos e depois seguir para o Brasil.

Nas palavras do agricultor e, no momento, trabalhador da construção civil, o tema da apropriação linguística aparece como uma questão de "ter" ou "não ter" o que pode pôr em risco a própria sobrevivência do imigrante. A fronteira política partilhada entre Brasil e Bolívia, através de Brasileia, Epitaciolândia e Cobija, acabou trazendo o espanhol para o cotidiano dos moradores desses municípios acreanos, transformando o castelhano em uma espécie de segunda língua para grande número de pessoas naquelas localidades, tornando, portanto, mais fácil a prestação de auxílio (quando o desejo for esse) aos imigrantes que já dominam esse idioma.

Para aqueles que têm como línguas apenas o francês e/ou o crioulo, conseguir um pouco de água, mesmo em uma relação comercial, torna-se uma difícil tarefa, quanto mais se o item desejado não está à vista e não pode ser demonstrado. Nesses casos, recorre-se a gestos e sons na tentativa de indicar aquilo que se deseja. E o que se deseja não é meramente aquilo que se está tentando pedir, mas o entendimento.

Por outro lado, ao mesmo tempo em que deixa transparecer o plano de rumar para "outros lugares", o narrador problematiza, com base na informação dada por "um amigo", a prestação de auxílio oferecida por acreanos e paulistas, evidenciando que a questão do entendimento ou da ajuda recebida, vai muito além da simples aquisição do idioma. Não saber se "em São Paulo ocorre isso", na fala de Fernando Jean Pierre, pode indicar a problemática da língua na relação com usos efetivados por seus praticantes e a comunicação. Esse questionamento se pauta na possibilidade de que o ato de tornar comum (SARLO, 2007) poderia ser mais fácil no Acre, "pois se você está com sede aqui no Acre você pode pedir água que lhe dão" e talvez, em São Paulo, "se morre de sede e não lhe dão de beber".

Esse interessante posicionamento, também elenca uma contradição, fruto do diálogo produzido pelo indivíduo no remoer de suas experiências. Se o entendimento e o auxílio prestados no Acre são mais acessíveis, o que impele o narrador a seguir para "outros lugares"? Uma das possíveis respostas a este questionamento, é a origem da informação reproduzida por Fernand Jean Pierre. Ela teria sido transmitida por um acreano e pode indicar muito mais a visão que este indivíduo elaborou sobre si mesmo, com base nas experiências por ele vivenciadas, do que naquilo que pôde ser observado por Fernand Jean Pierre. Como nos lembra Édouard Glissant, "há um equilíbrio precário entre o conhecimento 
de si e prática do outro" (GLISSANT, 2011, p. 143).

O não saber "se em São Paulo ocorre isso", encerra a dúvida de quem experimenta uma realidade diferente daquela enunciada pelo "amigo acreano". Realidade esta, marcada por todos os tipos de dificuldades, mesmo em um lugar em que "você pode pedir água que lhe dão". Nesse caso, o "Acre" que experimentam é o mesmo que eles querem deixar e isso termina por desdizer a afirmação de que o Acre seria um bom "destino" para os imigrantes do Haiti.

A compreensão do idioma possibilita o acesso a serviços e direitos, o que torna compreensível que aqueles que, mais facilmente dominem o português sejam "eleitos" como representantes e, nos mais diversos momentos, falem em nome do(s) grupo(s). Nas falas desses "representantes", novamente o "nós" (haitianos) figura no diálogo com o "eles" (brasileiros), re-significando o termo haitiano a partir das experiências no Acre. Isso não significa, no entanto, que a simples compreensão dos enunciados proferidos seja capaz de solucionar todas as tensões que esses contatos encerram. Outras fronteiras continuam de pé norteando a separação entre o nós e o eles. Diferenças quanto à condição social e/ou em relação à cor da pele continuam orientando práticas de inclusão e exclusão que visam, como observamos, a diminuição da condição humana de homens e mulheres no intuito de sua (deles) transformação em estimativas utilizáveis ou mão de obra sem vontade para o funcionamento do próprio sistema que os trata como excluidos.

Entre os dias 24 e 25 de janeiro de 2014, estivemos em Brasileia para mais uma vez verificar a situação dos haitianos que estavam naquele município. Mais de 1.200 pessoas dividiam e disputavam espaços no interior do abrigo improvisado há quase dois anos pelo governo acreano com pequena participação da administração federal. Tumultuadas filas se formavam ao redor dos pontos de retirada de documentos, nos postos de saúde, unidades bancárias, prédios dos correios; banheiros públicos e privados (nos postos de gasolina e na rodoviária) do município. No interior do alojamento o mau cheiro, as péssimas condições de higiene e de alimentação somam-se à desinformação generalizada quanto à utilidade de documentos e à obrigatoriedade de ali permanecer. Junto a tudo isso, um descontentamento visível na forma de falar e/ou nos comentários sobre a presença haitiana naqueles locais proferidos por atendentes comerciais e agentes nos postos da Receita e Polícia Federal evidenciam crescentes tensões resultantes da falta de compreensão existente entre praticantes de diferentes idiomas e do despreparo dos agentes públicos para lidar com as diferenças. Em todos os momentos do dia, grupos de haitianos (também senegaleses e dominicanos), caminhavam de um lado a outro da cidade buscando principalmente a documentação necessária para que pudessem sair do município. Em meio a essa espera e ao caminhar que, na maioria dos casos, termina sem que lhes sejam solucionados os casos, eles ocupam praças, calçadas e parques conversando em espanhol, crioulo e francês, procurando compreender o que ocorria, sempre buscando a superação das dificuldades.

Entre os munícipes de Brasileia, a presença haitiana era interpretada de forma negativa. Isso era facilmente perceptível nos olhares que se lançavam sobre as dezenas de sujeitos negros sentados ou andando nas calçadas daquela cidade; pelas enunciações racistas e xenófobas que são formuladas a respeito daqueles sujeitos; pelos comentários feitos em sussurros nos bancos, postos de saúde e agências de correio onde essas pessoas, como todas as outras, esperam para ser atendidas. Apesar de não ser um tratamento generalizado, essas manifestações de descontentamento em relação aos haitianos têm modificado as formas de proceder de alguns desses sujeitos no espaço público daquele município. Um deles chegou a dizer que o fato de tê-los andando, em todo momento, em grupos pelas ruas da cidade era "feio", mas que eles nada poderiam fazer, já que não possuíam a documentação necessária para seguir viagem em situação legal no país.

Identificados pela cor da pele e mal compreendidos em função do idioma, imigrantes 
de várias origens percorrem esse difícil trajeto entre o "nada" e o "pouco", representado pela aquisição de auxílio mediante o uso da palavra compreensível por aqueles que os recepcionam. Entre o "nada" e o "pouco" é local em que estão aqueles que esperam horas, dias e meses intermináveis por um atendimento (comunicado ou solução de questões pendentes) que parecem nunca chegar; "limbo" imposto pela carência de tradução da palavra enunciada. Enunciação presentificada nos grupamentos humanos que inscrevem com seus corpos negros tudo aquilo o que o verbo já havia dito, mas permanecia sem tradução para a língua local.

O transcurso linguístico, que segundo Fernando Jean Pierre, representa a diferença entre o "pouco" e o "nada" se apresenta como metáfora do caminho físico percorrido por eles de suas "terras natais" até o Brasil; dos alojamentos aos pontos de atendimento; entre Assis Brasil, Brasileia, Epitaciolândia, Rio Branco e "outros locais" brasileiros, essa trajetória entre o "pouco" e o "nada" se repete.

\title{
ENCOUNTERS AND DISENCOUNTERS OF HAITIAN NARRATIVES IN THE ACREAN AMAZON
}

\begin{abstract}
Between 2010 and 2014, thousands of Haitian subjects entered Brazilian territory through the border cities between Acre and Bolivia and Peru. Through this path, in the encounter with the locals and dialoguing with the discourses about their presence in Brazil, these subjects elaborated different forms of identification. In this study, we seek to understand how these dialogues influence(d) the lives of those who experienced these sociocultural circumstances, in the middle of a tense juridical/linguistic debate centred on the concept of the "legality" of their presence/permanence in Brazil. We collected data through interviews, newspapers and various other materials, gathered with the purpose of reflecting on the narratives produced by and about these subjects. Our approach was based on the works of Stuart Hall, Paul Ricoeur, Hannah Arendt and Edouard Glissant among others, who are fundamental authors to understand the level of violent stereotyping currently assigned to populations of African descent in the American continent.
\end{abstract}

\section{KEYWORDS}

Haitian diaspora, Identitarian narratives, Translation experiences, Acrean Amazon

\section{REFERÊNCIAS}

ASSARÉ, P. Cante lá que eu canto cá. Petrópolis: Vozes, 1978.

ADORNO, T. W.; HORKHEIMER, Max. Dialética do esclarecimento. Trad. Guido Antonio de Almeida. Rio de Janeiro: Jorge Zahar Editor, 1985.

ALBUQUERQUE, G. R. Diáspora de afrocaribenhos para a Amazônia acreana. In: ALBUQUERQUE, G. R. \& ANTONACCI, M. A. (Orgs.). Desde as Amazônias - Colóquios 1. Rio Branco: Nepan Editora 2014, pp. 171-210. ALBUQUERQUE, G. R. Trabalhadores do Muru, o rio das cigarras. Rio Branco: EDUFAC, 2005.

ANTONACCI, M. A. Memórias ancoradas em corpos negros. São Paulo: Educ, 2013.

ARENDT, H. A condição humana. Trad. Roberto Raposo. 4. ed., Rio de Janeiro: Forense Universitária, 1989.

ARENDT, H. Origens do totalitarismo. Trad. de Roberto Raposo. 7. reimpressão, São Paulo: Cia das Letras, 2007. ARENDT, H. Sobre a violência. Tradução de André de Macedo Duarte. Rio de Janeiro: Civilização Brasileira, 2009.

BAUMAN, Z. O mal-estar da pós-modernidade. Rio de Janeiro: Editora Jorge Zahar, 1998.

BAUMAN, Z. Vida líquida. Rio de Janeiro: Editora Jorge Zahar, 2005.

BENJAMIN, Walter. Magia e técnica, arte e política. Obras escolhidas, v.1. 3. ed. Brasiliense: São Paulo, 1987.

BOSI, E. Memória e sociedade: lembrança de velhos. São Paulo: Companhia das Letras, 1998.

BUTLER, J. Actos performativos y construción del género: um ensayo sobre fenomenología y teoria feminista. 2009. Disponível em <www.debatefeminista. com/PDF/articulos/actosp433.pdf>. Acesso em 06/03/2014.

CALDEIRA, T. Memória e relato: a escuta do outro. In: Revista do Arquivo Municipal - Memória e ação cultural. v. 200, São Paulo: DPH, 1992.

CHAUI, M. Conformismo e resistência: aspectos da cultura popular no Brasil. 4. ed., São Paulo, Brasiliense, 1986. ELIADE, M. Mito e realidade. 6. ed., São Paulo: Perspectiva, 2002.

FANON, F. Os condenados da terra. Tradução de Enilce Albergaria Rocha e Lucy Magalhães. Juiz de Fora (MG): 
Editora da UFJF, 2006.

FISCHER, E. A necessidade da arte. 6. ed., Tradução de Leandro Konder. Rio de Janeiro: Jorge Zahar Editora, 1977.

GALEANO, E. A história do Haiti é a história do racismo na civilização ocidental. 2010. Disponível em: <http:// developmentissues.wordpress.com/2010 /01/ 19/racism-haiti/>. Acesso em: 28/02/2014.

GERLIN, Guinot. Entrevista, Rio Branco, Acre 28/04/2013.

GERLIN, Guinot. Entrevista, Rio Branco, Acre, 11/08/2013.

GILROY, P. O Atlântico negro: modernidade e dupla consciência. Tradução de Patrícia Farias. São Paulo: Editora 34, 2001.

GLISSANT, E. Introdução a uma poética da diversidade. Tradução de Enilce Albergaria Rocha. Juiz de Fora (MG): Editora da UFJF, 2005.

GLISSANT, E. Poética da relação. Tradução de Manuela Mendonça. Portugal: Porto Editora, 2011.

HALL, S. A centralidade da cultura: notas sobre as revoluções culturais do nosso tempo. Educação \& Realidade, Porto Alegre, v. 22, n. 2, jul./dez. 1997, pp. 15-46.

HALL, S. A identidade cultural na pós-modernidade. Rio de janeiro: DP\&A, 2006.

HALL, S. Da diáspora. Identidades e mediações culturais. Belo Horizonte: Editora da UFMG, 2003.

HARENDT, H. A condição humana. Trad. Roberto Raposo. 4. Ed., São Paulo: Companhia das letras, 1989.

JAMES, C. L. R. Os Jacobinos negros: Toussaint L'Ouverture e a Revolução de São Domingos. Tradução de Afonso Teixeira Filho. São Paulo: Boitempo, 2000.

JEAN PIERRE, Fernand. Entrevista, Brasiléia, Acre, 31/01/2012.

JEAN PIERRE, Fernando. Entrevista, Rio Branco, Acre, 02/04/2012.

JOSEPH, Leonel. Entrevista concedida ao Blog do Altino Machado, Brasiléia, Acre, 18/04/2011.

PERROT, M. Os excluídos da História: operários, mulheres, prisioneiros. Rio de Janeiro: Paz e Terra, 1988.

PRATT, M. L. Os olhos do império: relatos de viagem e transculturação. Tradução de Jézio Gutierre. Bauru: EDUSC, 1999.

RICOEUR, P. A identidade narrativa e o problema da identidade pessoal. Tradução de Carlos João Correia. Arquipélago. n. 7, 2000, pp.177-194.

RICOEUR, P. Identidade Narrativa I. Tradução de Constansa Marcondes Cesar. Papirus Editora: São Paulo, 1994. SARLO, B. Tempo passado: cultura da memória e guinada subjetiva. Tradução de Rosa Freire D’aguiar. São paulo: Companhia das Letras; Belo Horizonte: UFMG, 2007.

PETIT, Tervenkus. Entrevista, Rio Branco, Acre, 02/06/2013.

PETIT, Tervenkus. Entrevista, Rio Branco, Acre, 01/08/2013.

Data de recebimento: 12/03/2016

Data de aceite: $29 / 04 / 2016$ 